\title{
Ovarian function in suckling and non-suckling beef cows post partum
}

\author{
H. M. Radford, C. D. Nancarrow and P. E. Mattner
}

C.S.I.R.O. Division of Animal Production, P.O. Box 239, Blacktown, New South Wales 2148, Australia

\begin{abstract}
Summary. Two groups, each of 7 crossbred beef cows, which were suckling or not suckling calves, were fed a high quality food ad libitum for 3 months post partum. The non-suckling cows experienced regular ovarian cycles from 10-33 days post partum while the suckling cows did not do so until at least 14 weeks post partum. There was little difference between the groups in growth rate or in plasma glucose concentration. The plasma prolactin concentrations in the non-suckling cows showed a seasonal trend which paralleled ambient temperature and daylight hours; in the suckling cows this trend was less evident. Plasma LH concentrations were lower in suckling cows before Day 30 post partum but were similar thereafter. Most suckling cows also failed to experience oestrus or to exhibit $\mathrm{LH}$ release in response to an injection of oestradiol benzoate at about 6 weeks post partum. This failure, together with the earlier lower levels of LH in the suckling cows, is considered to be indicative of malfunction of the hypothalamic mechanism normally responsible for the establishment and maintenance of cyclic ovarian function.
\end{abstract}

\section{Introduction}

Despite many studies on the development of ovarian activity post partum in both beef and dairy cattle (e.g. Edgerton \& Hafs, 1973; Oxenreider \& Wagner, 1971; Riesen, Saiduddin, Tyler \& Casida, 1968), there is incomplete understanding of the nutritional and endocrine mechanisms underlying the return to regular ovarian function in the post-partum cow.

The study reported here was undertaken as an early step in investigation of this problem. It was designed to determine the onset of ovarian function post partum in beef cows with and without calves, in a situation in which feed supply was not limiting.

\section{Location}

\section{Materials and Methods}

The experiment was undertaken at the C.S.I.R.O. Division of Animal Production, Prospect, in the central coastal region of New South Wales, Australia during the winter and spring of 1975.

\section{Animals and their assignment to groups}

The cows were Angus-Friesian and Hereford-Friesian crosses which had been artificially inseminated with semen from a polled Hereford bull following an oestrus synchronization programme with the prostaglandin F-2 $\alpha$ analogue, cloprostenol (I.C.I., Australia). The cows were maintained in good condition at pasture until calving. At calving each animal was assigned to one of two groups; in Group I the cows suckled their calves, in Group II the calves were removed within 2 days of birth. There were 4 Angus-Friesian and 3 Hereford-Friesian crossbreds in each group. All animals calved between 19 May and 13 June.

\section{Housing, feeding and weighing}

During the first few weeks after calving, the groups were maintained in separate small outside enclosures, with sufficient food and water to prevent competition while feeding and drinking. The 
animals were then moved to a covered, open-sided barn with access to individual feeding and watering pens and to outside exercise areas. The groups were in sight of each other but were physically separated throughout. The cows were fed ad libitum with a mixture of 60:40 parts by weight of chopped lucerne hay and rolled oats, and were returned to pasture approximately 12 weeks post partum. Throughout the experiment the animals were weighed once weekly.

\section{Detection of oestrus}

Heat-mount detectors (Kamar Inc., Steamboat Springs, Colorado, U.S.A.) were fitted to all cows and examined daily, and a penis-deviated bull fitted with a chin-ball marker (Lang, Hight, Uljee \& Young, 1968) was run continuously with each group. Records were kept of activated and missing heat-mount detectors, of the occurrence of chin-ball marks on the backs and flanks of the cows and of observed mounting by other cows or the bull. Additionally, the ovaries and uterus of each cow were examined by palpation per rectum at approximately weekly intervals from 2 weeks post partum.

\section{Ovarian and pituitary hormones and blood glucose determinations}

Samples of jugular venous blood were collected by venepuncture into heparinized syringes twice weekly. The samples were stored in crushed ice until centrifugation about $1 \mathrm{~h}$ later. The decanted plasma samples were stored at $-10^{\circ} \mathrm{C}$ until assayed for progesterone, $\mathrm{LH}$, prolactin and glucose.

Progesterone, in $0.5 \mathrm{ml}$ plasma, was measured by protein-binding assay, which was a modification (Thorburn \& Schneider, 1972) of the method of Bassett \& Hinks (1969). The results have not been corrected for recovery, which varied from 82 to $87 \%$ over the range $1-8 \mathrm{ng} / \mathrm{ml}$. Water blanks were less than $0.1 \mathrm{ng} /$ tube, and sensitivity of the assay, defined as twice the s.d. of blank values, was $0 \cdot 1$ $\mathrm{ng} /$ tube. The within- and between-assay coefficients of variation were $<16 \%$ over the range $1-8$ $\mathrm{ng} / \mathrm{ml}$. LH was measured by radioimmunoassay (Goding et al., 1969) with an antiserum raised in a mare against NIH-LH-B3. The antiserum did not cross-react with bovine prolactin or growth hormone but there was a $2 \%$ cross-reaction with bovine FSH (NIH-FSH-B1) and a $12 \%$ cross reaction with bovine TSH (NIH-TSH-B3). A laboratory purified ovine $\mathrm{LH}$ was used as iodinated tracer and NIH-LH-B5 as standard. Plasma samples high in LH diluted out parallel with the standard curve. The sensitivity of the assay, defined as twice the s.d. of zero values, was $0.9 \mathrm{ng} / \mathrm{ml}$ and the between- and within-assay coefficients of variation were less than $10 \%$ over the range $1-80 \mathrm{ng} / \mathrm{ml}$. Prolactin was measured by the radioimmunoassay of Ślebodzinski \& Wallace (1977), with an antiserum raised in a rabbit against ovine prolactin. The antiserum did not cross-react with up to 20 mu ACTH or $320 \mathrm{ng}$ of NIH preparations of bovine FSH, LH, TSH or growth hormone. NIH-P-B2 was used as standard and NIH-P-S6 as iodinated tracer. Above a dilution of 1 in 4, plasma samples diluted out parallel with the standard curve. Samples were always diluted 1:10 for assay. Sensitivity of the assay was $0.5 \mathrm{ng} / \mathrm{ml}$ and the within- and between-assay coefficients of variation were $<15 \%$ over the range $1-50 \mathrm{ng} / \mathrm{ml}$. Glucose was estimated by the method of Huggett \& Nixon (1957).

\section{Responses to cloprostenol and oestradiol benzoate}

At approximately 6 weeks post partum, when the data indicated an existing difference in ovarian status between the two groups, all cows were injected subcutaneously with cloprostenol at 09:00$09: 30 \mathrm{~h}$ on the same day; $27 \mathrm{~h}$ later each cow received an intramuscular injection of $500 \mu \mathrm{g}$ oestradiol benzoate in $2 \mathrm{ml}$ peanut oil. Jugular blood samples were collected at 0 and $7 \mathrm{~h}$ after the cloprostenol treatment, and at $-3,+4,+18,+21,+24,+27,+30,+33$, and $+45 \mathrm{~h}$ from the oestradiol injection. The occurrence of oestrus was also recorded at these times.

After the cows had been returned to pasture, they were again injected with cloprostenol but only those of Group I were also treated with oestradiol benzoate. Daily blood samples were collected and observations for the occurrence of oestrus were again made. 


\section{Results}

There were no differences between Angus-Friesian and Hereford-Friesian crossbreds in any of the parameters compared, so no further account is taken of these breed differences in presentation of the results.

\section{Changes in liveweight of cows and calves}

The changes in mean liveweight of the two groups of cows and of the calves are shown in Text-fig. 1. The difference in mean liveweight between the two groups was due largely to a very heavy cow (No. 87) in Group II and a relatively light cow (No. 100) in Group I. With the exception of Cow 100, none weighed less than $430 \mathrm{~kg}$ immediately after calving; Cow 100 weighed $370 \mathrm{~kg}$ at calving and reached $400 \mathrm{~kg}$ liveweight within 1 month. During the first 2-3 weeks post partum the cows of Group II increased in weight faster than those of Group I, but this difference disappeared by the end of the first month post partum. A sudden loss in body weight around Day 40 in the cows with calves (see Text-fig. 1) was associated with extremely cold, wet and windy conditions. After this the rates of gain of the two groups of cows were again similar until the return to pasture in August when the cows of Group I lost weight more rapidly than those of Group II.

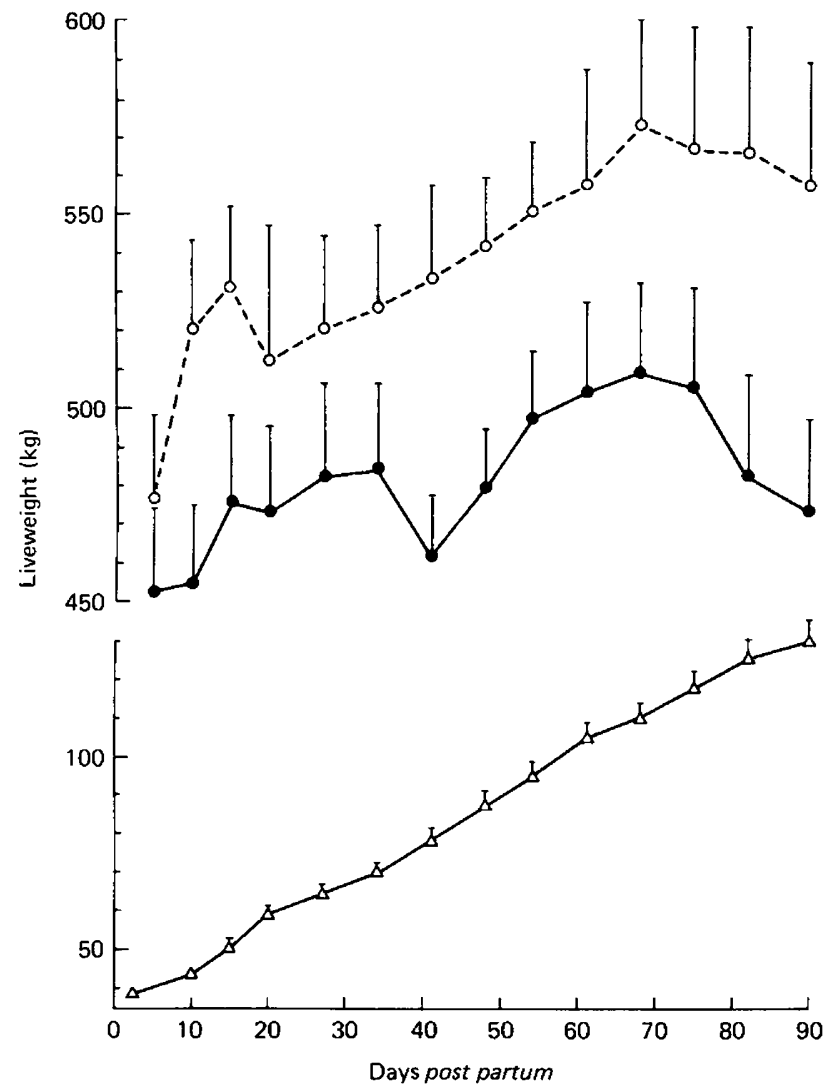

Text-fig. 1. Changes in mean liveweight ( \pm s.e.m.) of cows with calves $(\bullet)$, cows without calves $(O)$, and of calves $(\triangle)$. Each point represents the mean of values recorded on day indicated, \pm 2 days to Day $20, \pm 3$ days thereafter.

\section{Oestrus, ovulation and plasma progesterone concentrations}

The heat-mount detectors were of limited value in detecting oestrus in Group I because the calves became most adept at removing the devices when their mothers were lying down, Howkever, chin-ball $\therefore$ :Lis 
marks were invariably associated with activated detectors when the latter were present, and with the occasional direct observations of cows being mounted by others. Accordingly, chin-ball marks have been taken as proof of oestrus. The occurrence of oestrus in all cows is indicated in Text-fig. 2. In Group II the mean interval to first oestrus post partum was 22 days (range 10-33) while in Group I only 3 cows exhibited oestrus (at 58,80 and 89 days post partum) by the time of the second injection of oestradiol benzoate (see below).

There was a clear difference between the changes in plasma progesterone concentrations in the two groups of cows (Text-fig. 2). By 6 weeks post partum, when cloprostenol was first injected, all cows of Group II were experiencing apparently normal cycles of progesterone secretion, while only one of Group I was doing so. This disparity was maintained throughout the first 3 months of the experiment.

(a) Cows with calves

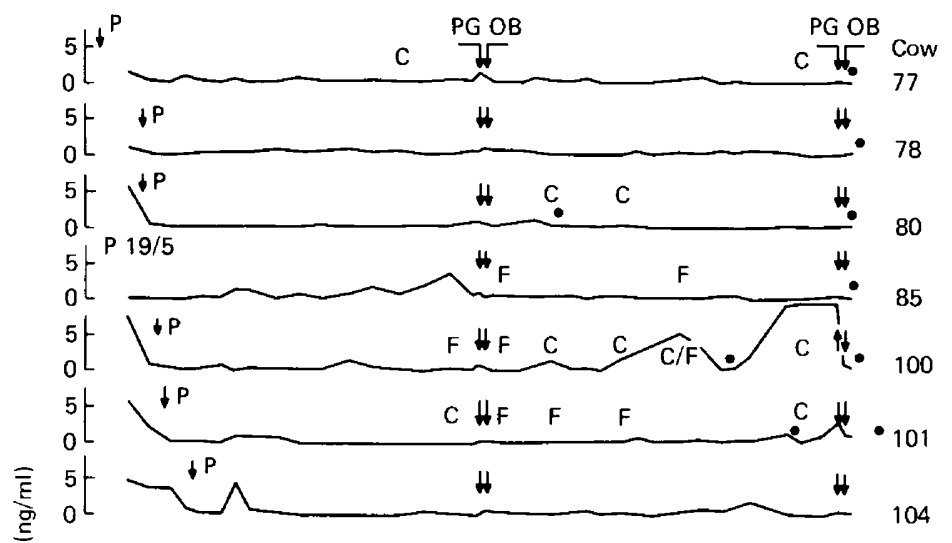

(b) Cows without calves

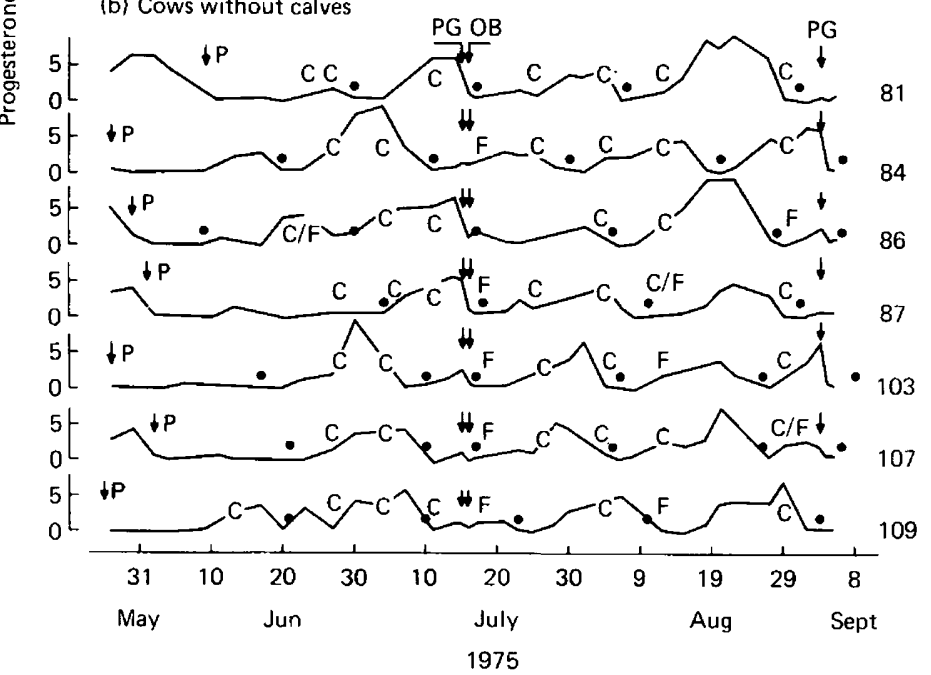

Text-fig. 2. Changes in plasma progesterone concentration, occurrence of oestrus, and presence of palpatable corpora lutea and Graafian follicles in individual cows. $\mathrm{P}$, parturition; $\bullet$, oestrus; $\mathrm{C}$, corpus luteum; F, Graafian follicle $>1 \mathrm{~cm}$ diameter. Times of cloprostenol (PG) and oestradiol benzoate (OB) injections are indicated by appropriate vertical arrows.

The detection of corpora lutea and of large follicles by rectal palpation (Text-fig. 2) in general accorded well with the patterns of plasma progesterone concentration. 


\section{Response to injected cloprostenol and oestradiol benzoate}

The behavioural and hormonal responses to these injections at 6 weeks post partum are shown in Text-fig. 3. In Group I there was no evidence of luteal regression, oestrus or formation of corpora lutea and only one cow exhibited an LH surge. In contrast, luteal regression, and oestrus within 3 days, occurred in 5 of the cows of Group II. A fresh corpus luteum formed in all 5, although an LH surge was detected in only 4 of them. The 2 animals of this group which did not respond to cloprostenol were apparently injected too early in the cycle for the cloprostenol to be luteolytic (Rowson, Tervit \& Brand, 1972). The changes in plasma prolactin concentration, also included in Text-fig. 3, were very variable; they wete neither consistently similar within a group nor consistently different between the groups.

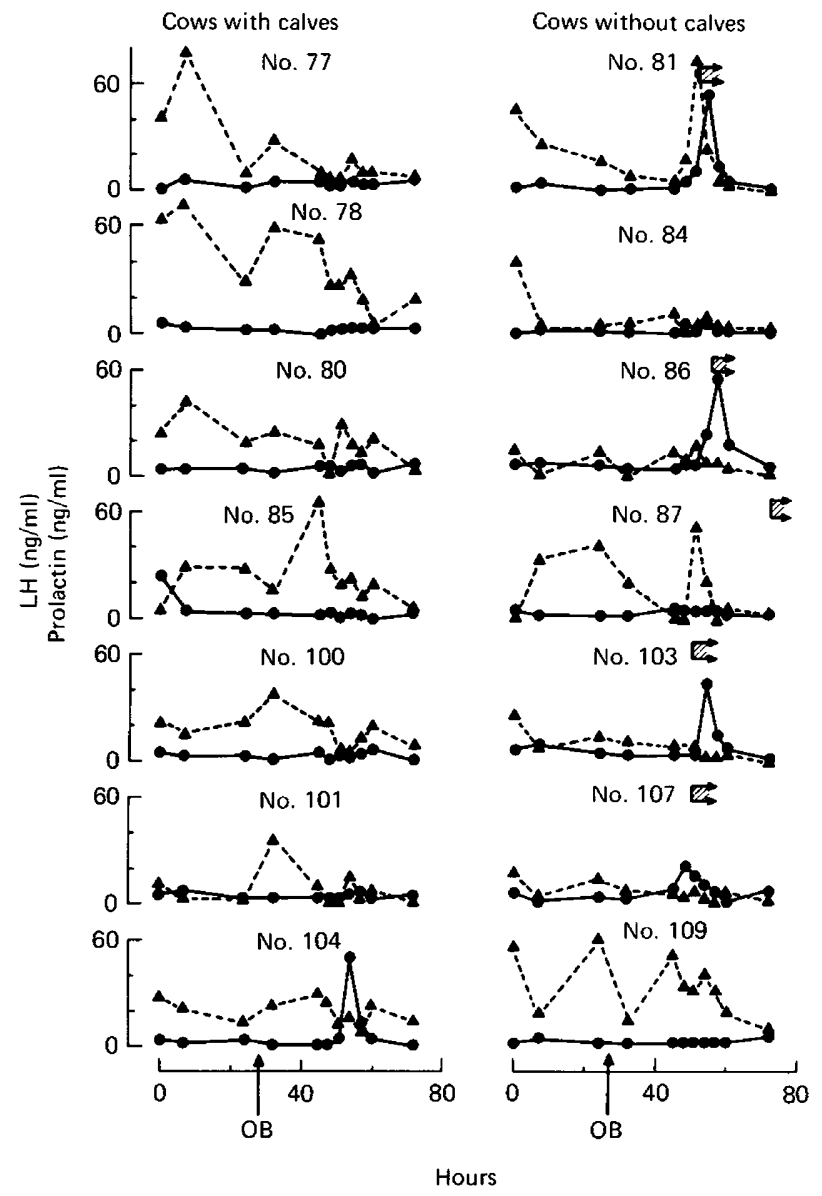

Text-fig. 3. Changes in plasma concentrations of $\mathrm{LH}(--\infty)$ and prolactin $(\Delta---\Lambda)$ and the occurrence of oestrus $\mathbb{Z}$, after injections of cloprostenol (at $0 \mathrm{~h}$ ) and, $27 \mathrm{~h}$ later, of oestradiol benzoate (OB) 6 weeks after calving.

When cloprostenol and oestradiol benzoate were injected 14 weeks post partum, 5 of the Group I cows had not experienced an ovarian cycle and 4 of these responded by coming into oestrus within $24 \mathrm{~h}$. One of the 2 cows which had experienced an ovarian cycle had a mature corpus luteum, and luteal regression and oestrus occurred as expected in response to cloprostenol. The other, injected 6 days after its first post-partum oestrus, did not come into oestrus for a further 6 days. One of the cows of Group II was in oestrus on the day of cloprostenol injection and was therefore not treated. 
Of the remaining 6 cows injected with cloprostenol only, 4 came into oestrus $2-4$ days later; the other 2 had exhibited oestrus 2-4 days before injection and neither luteal regression nor oestrus occurred.

\section{Changes in plasma concentrations of $L H$, prolactin and glucose}

Excluding those occasions when blood samples may have been taken during the course of an ovulatory surge of $\mathrm{LH}$, the $\mathrm{LH}$ levels in both groups of cows were invariably less than $10 \mathrm{ng} / \mathrm{ml}$ plasma, and, particularly during the first 30 days post partum, the levels in Group I were usually significantly lower than in those of Group II (Text-fig. 4a).
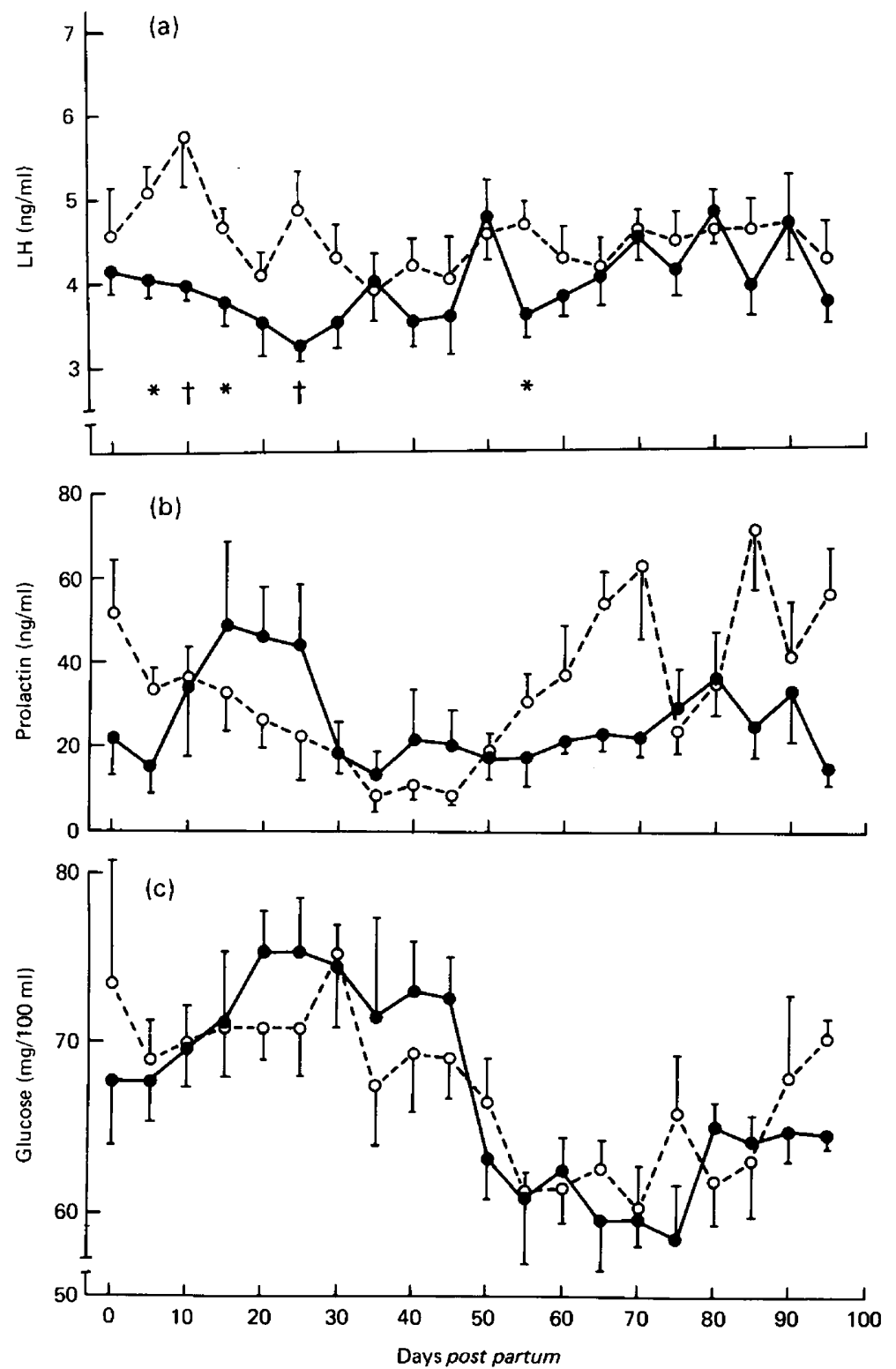

Text-fig. 4. Changes in mean plasma concentration $( \pm$ s.e.m.) of (a) LH, (b) prolactin, and (c) glucose in cows of Group I (e, suckling) and Group II (O, not suckling). Each point represents the mean of values recorded on the day indicated \pm 2 days. In (a) times when means differed significantly are indicated by ${ }^{*}$ $(P<0.05)$ or $\dagger(P<0.01)$ (Student's unpaired $t$ test, two tailed). 
There was considerable variation between and within animals in plasma prolactin concentration (Text-fig. 4b). There were significant differences between groups at different times, but these were not consistently in one direction.

There were no significant differences between the mean concentrations of plasma glucose for each of the groups at any time post partum (Text-fig. 4c).

\section{Discussion}

There was a clear difference between cows without calves and suckling cows in the time of onset of cyclic ovarian activity post partum, within 5 weeks for the former but not until 14 weeks post partum in the latter. Hypoglycaemia has been proposed as a cause of infertility in lactating cows (McClure, 1970). There was no evidence of hypoglycaemia in the present study in which the levels of plasma glucose were similar in both groups of cows. It seems unlikely also that the difference in ovarian activity between the groups was related to differences in liveweight or liveweight change (Wiltbank, Bond \& Warwick, 1965). Differences in ovarian function between the groups had been established by 5 weeks after calving although all cows had improved in body condition by then, as indicated by the rise in liveweight (see Text-fig. 1), and no cow weighed less than $370 \mathrm{~kg}$ at any time during the study. Neither the cause nor the effect of the weight loss which occurred in the cows around 40 days post partum can be determined. It may have been a reflection of the inability of the suckling cows to consume enough food, even though this was always available, when the maintenance requirements must have been high because of the cold conditions. However, since the weight loss was of short duration, and was recovered, it seems unlikely that it was an important contributory factor to maintenance of the established difference in ovarian activity.

The basic cause of this difference in ovarian activity cannot be determined from our data. The inhibition of ovarian activity in the suckling cows could perhaps be due to the association of mother and offspring, which may inhibit ovarian activity in rats (Moltz, Levin \& Leon, 1969), to neuroendocrinological aspects of suckling, or to a drain of nutrients by milk removal. The present study did not permit any assessment of the consequences of social interaction between the cow and her calf, and although energy supply to the cows was apparently not limiting, nothing was known of other aspects of nutrient status.

The blood sampling schedules used were not designed to examine endocrine changes specifically associated with the act of suckling. Certainly the bursts of prolactin secretion which occur during suckling (Karg \& Schams, 1974), and which may be implicated in inhibition of ovarian function (Kann \& Martinet, 1975; Maneckjee, Srinath \& Moudgal, 1976) would not have been detected. Accordingly our data on prolactin concentration probably reflect basal prolactin secretion on which would be superimposed any response to handling involved in the blood sampling procedures (Fell et al., 1972; Cumming, Brown, Goding, Bryant \& Greenwood, 1972; Karg \& Schams, 1974). There was no continuing correlation between high prolactin concentration and ovarian inactivity in the suckling cows although a seasonal pattern in prolactin was evident in the non-suckling cows. This pattern apparently paralleled the changes which undoubtedly occurred, but which were not measured, in daily temperature and daylight hours during the period of the study-early winter to early spring. Similar associations have been reported by Karg \& Schams (1974) and Smith, Hacker \& Brown (1977).

During the first 30 days post partum the mean plasma LH concentrations in the suckling cows were lower than in the non-suckling cows and is considered to be due to reduced hypothalamopituitary function at this time. That such a state did exist is supported by the results of the tests with cloprostenol and oestradiol benzoate; most of the suckling cows failed to experience oestrus and to release $\mathrm{LH}$ in response to the injection of oestradiol benzoate at around 40 days post partum. This failure undoubtedly occurred in the hypothalamus (see Radford \& Wallace, 1974) and, to our knowledge is the first demonstration of failure of any specific part of the reproductive control system in the post-partum cow. Whether it is a feature common to all instances of post-partum anoestrus in cattle remains to be determined, as does its underlying cause. 
We thank Professor T. J. McClure, University of Sydney, for fruitful discussions; Mr J. Avenell, Mr P. J. Connell, Mr T. J. Morris and Mr K. E. Hollis for their invaluable technical assistance throughout; and Ms A. White who carried out the analysis for plasma glucose.

\section{References}

BASSETT, J.M. \& Hinks, N.T. (1969) Microdetermination of corticosteroids in ovine peripheral plasma; effects of venepuncture, corticotrophin, insulin and glucose. $J$. Endocr. 44, 387-403.

Cumming, I.A., Brown, J.M., Goding, J.R., Bryant, G. \& GReenwood, F.C. (1972) Secretion of prolactin and luteinizing hormone at oestrus in the ewe. J. Endocr. 54, 207-213.

EdGerton, L.A. \& HAFS, H.D. (1973) Serum luteinizing hormone, prolactin, glucocorticoid, and progestin in dairy cows from calving to gestation. J. Dairy Sci. 56, $451-458$.

Fell, L.R., BeCK, C., Brown, J.M., CATt, K.J., Cumming, I.A. \& Goding, J.R. (1972) Solid-phase radioimmunoassay of ovine prolactin in antibodycoated tubes. Prolactin secretion during estradiol treatment, at parturition, and during milking. Endocrinology 91, 1329-1336.

Goding, J.R., CatT, K.J., Brown, J.M., Kaltenbach, C.C., Cumming, I.A. \& Mole, B.J. (1969) Radioimmunoassay for ovine luteinizing hormone. Secretion of luteinizing hormone during estrus and following estrogen adminstration in the sheep. Endocrinology 85, 133-142.

Huggett, A.St.G. \& Nixon, D.A. (1957) Use of glucose oxidase, peroxidase and $\mathrm{O}$-dianisidine in determination of blood and urinary glucose. Lancet 273, 368-370.

KanN, G. \& Martinet, J. (1975) Prolactin levels and duration of postpartum anoestrus in lactating ewes. Nature, Lond. 257, 63-64.

KARG, H. \& Schams, D. (1974) Prolactin release in cattle. J. Reprod. Fert. 39, 463-472.

Lang, D.R., Hight, G.K., Ulueee, A.E. \& Young, J. (1968) A marking device for detecting oestrus activity of cattle. N. Z. Jl agric. Res. 11, 955-958.

Maneckjee, R., SRinath, B.R. \& Moudgal, N.R. (1976) Prolactin suppresses release of luteinising hormone during lactation in the monkey. Nature, Lond. 262, 507-508.

McClure, T.J. (1970) An experimental study of the causes of a nutritional and lactational stress in- fertility of pasture-fed cows, associated with a loss of bodyweight at about the time of mating. Res. vet. Sci. 11, 247-254.

Moltz, H., Levin, R. \& Leon, M. (1969) Prolactin in the postpartum rat: synthesis and release in the absence of suckling stimulation. Science, N.Y. 163, 1083-1084.

Oxenreider, S.L. \& Wagner, W.C. (1971) Effect of lactation and energy intake on postpartum ovarian activity in the cow.J. Anim. Sci. 33, 1026-1031.

Radford, H.M. \& Wallace, A.L.C. (1974) Central nervous blockade of oestradiol-stimulated release of luteinizing hormone in the ewe. J. Endocr. 60, 247252.

Riesen, S.L., Saiduddin, S., Tyler, W.J. \& Casida, L.E. (1968) Relation of postpartum interval to corpus luteum development, pituitary prolactin activity and uterine involution in dairy cows (effect of suckling). Res. Bull. agric. Exp. Stn Univ. Wis. No. 270.

Rowson, L.E.A., Tervit, R. \& Brand, A. (1972) The use of prostaglandins for synchronization of oestrus in cattle. J. Reprod. Fert. 29, 145, Abstr.

Sllebodzínski, A.E. \& Wallace, A.L.C. (1977) Pituitary and thyroidal responses to synthetic thyrotrophin releasing hormone in two breeds of cattle. J. Endocr. 75, 1-13.

SMith, V.G., Hacker, R.R, \& Brown, R.G. (1977) Effect of alterations in ambient temperature on serum prolactin concentration in steers. J. Anim. Sci. 44, 645-649.

Thorburn, G.D. \& SchneIder, W. (1972) The progesterone concentration in the plasma of the goat during the oestrous cycle and pregnancy. J. Endocr. 52, 23-36.

Wiltbank, J.N., BOND, J. \& WARWICK, E.J. (1965) Influence of total feed and protein intake on reproductive performance of the beef female through second calving. U.S. Dep. Agric. Tech. Bull. No. 1314.

Received 12 October 1977 